\title{
The dependency between annual air temperature and solar activity. A case study of Warsaw in 1951-2010.
}

\begin{abstract}
The paper demonstrates a dependency between the annual average daily air temperature course (cycle) in Warsaw and the profile of annual solar activity linked to rotation (with a period of 25-31 days). Waves of cold $(\Delta T<0)$ or heat $(\Delta T \geq 0)$ were defined as $\Delta T$ deviations of daily average temperature $(T)$ using a regression sinusoid $f(t)$ with a period of 365 days. Cold waves were found to generally occur at times of low daily average solar activity (relative to 60-year average), while hot waves tended to coincide with high Wolf numbers. The cycles of the variables were derived using the sinusoid regression method (Boryczka 1998). The maximum sinusoid regression of the annual air-temperature cycle $T$ is delayed by nearly one month vis-à-vis the maximum declination of the Sun. The maximum of the regression sinusoid of daily average Wolf numbers $(W)$ was delayed from the maximum declination by more than two months.
\end{abstract}

Keywords

Cold waves $\cdot$ heat waves $\cdot$ solar activity $\cdot$ regression sinusoid $\bullet$ period interference

(C) University of Warsaw - Faculty of Geography and Regional Studies

Introduction

The main objective of this paper is to determine the influence of solar activity, as observed from the Earth, on the annual course of air temperatures using Warsaw over the period 1951-2010 as a case study.

In the study of the annual air temperature course a particularly important role is played by annual, or shorter, cycles of solar activity linked to the Earth's orbiting around the Sun (365.25 days) and the Sun's rotation around its axis inclined at an angle of $82^{\circ} 45^{\prime}$ to the plane of the ecliptic (with an inclination of the equator of $\left.7^{\circ} 15^{\prime}\right)$. The Sun has a rotation period of 25.04 days at its equator and 31 days near its poles.

The dominant contribution of solar radiation in shaping the Earth's climate during the gradual warming of the climate in the $19^{\text {th }}$ to $20^{\text {th }}$ century is evidenced by the synchronic changes of average air temperature in the northern hemisphere in the years 1856-2002 (Bernes, 2003) and 11-year moving average Wolf numbers (Boryczka, Stopa-Boryczka, 2004). The years 1920-2002 are characterised by significant warming, with a local minimum in the 1970s. The same is true of the deviation of the consecutive averages of Wolf numbers for the same periods. The main local minimum of the Wolf numbers corresponds to the main local minimum of the temperature in the 1970s; solar activity in the years 1925-2002 is also much greater than before 1925 .

Changes in air temperature $T$ (11-year moving average) in Europe (Paris, Berlin, Stockholm, Warsaw, Cracow, Prague, Vienna, Tallinn, Basel, Oxford) and solar activity $W$ in the years 1840-1994 are described by regression equations (1) and (2), with correlation coefficients of $r=0.913$ and $r=0.612$, with statistical significance at $<0.01$ (Boryczka, 2015)
Jerzy Boryczka', Maria Stopa-Boryczka², Urszula Kossowska-Cezak ${ }^{3}$, Jolanta Wawer ${ }^{4}$

"Institute of Physical Geography,

Faculty of Geography and Regional Studies

University of Warsaw, Poland

e-mail: jkborycz@uw.edu.pl

2Institute of Physical Geography,

Faculty of Geography and Regional Studies

University of Warsaw, Poland

e-mail: mmstopab@uw.edu.p

${ }^{3}$ Institute of Physical Geography,

Faculty of Geography and Regional Studies

University of Warsaw, Poland

4Institute of Physical Geography,

Faculty of Geography and Regional Studies,

University of Warsaw,, Poland

e-mail: jgwawer@uw.edu.pl

Received: 14 May 2016

Accepted: 24 July 2017

$T=0.007131 t-5.16899$

$W=0.262018 t-445.6094$

The dependency between annual air temperature (11-year moving average) in Europe in the years 1840-1994 and solar activity is described by equation (3), with correlation coefficient of $r=0.628$, and statistical significance at $<0.01$.

$$
T=0.01150 W+7.86782
$$

The annual course of air temperature $(T)$, represented by (60year) average daily values from continuous 365-day strings over the period $1951-2010$ is illustrated by a curve with numerous peaks and troughs representing short hot and cold spells, or waves.

Examples include the cold waves in May and summer known in Poland under a variety of colourful names including, "the cold gardeners" (from patron saints Pancras, Servatius and Boniface on 12-14 May), "the cold Sophie" (patron saint of 15 May), and "the European monsoon" (June) (Kossowska-Cezak, 1994); the Indian summer hot waves known as "babie lato" (September and October); and winter warm and cold waves captured in a folk proverb "If St Barbara's (4 December) is wet then Christmas (25 December) will be icy" (Stopa-Boryczka et al., 2006).

The sources used in the study included daily air temperatures in Warsaw measured during the period 1951-2010 which were obtained from the archives of the Institute of Meteorology and Water Management. Daily values of the NAO index covering the 
period 1951-2012 and daily Wolf numbers from 1951-2013 were downloaded from the on-line service at the address daily total sunspot number,. dayssn import.txt.

Spectrums and cycles of air temperature $(T)$ in Warsaw, NAO index and Wolf numbers $(W)$ ranging from 1 to 365.25 days in length were identified using the regression sinusoid method proposed by J. Boryczka (1998).

The regression sinusoid method developed by J. Boryczka consists in adjusting the results of the $y_{1}, \ldots, y_{n}$ measurements performed in time $t_{1}, \ldots, t_{\mathrm{n}}$ (using the smallest square values) of consecutive sinusoids with presumed cycles, e.g. $\Theta=1,2, \ldots, n$ (or $0.1,0.2, \ldots, n$ ) according to regression sinusoid equation (4),

$y=a_{0}+b \sin \left(\frac{2 \pi}{\Theta} t+c\right)$

where: $\Theta$ - period, $b$ - amplitude, $c$ - phase, $t$ - time, by changing the period of sinusoid $\Theta$ every 0.1 day.

The spectrum is a sequence of the values of residual variance $\varepsilon^{2}, \ldots, \varepsilon^{2}{ }_{n}$ corresponding to the presumed cycles $Q=0.1$, $0.2, \ldots, n$. Periods $\Theta$ - these are local minimal values of residual variance $\varepsilon^{2}$ (local maximum values of correlation coefficient $R)$ - equation (5).

$\varepsilon^{2}=\frac{1}{n} \sum_{i=1}^{n} \varepsilon_{i}^{2}, \quad R=\sqrt{1-\frac{\varepsilon^{2}}{s^{2}}}$

where $\varepsilon_{i}=y_{i}-y\left(t_{i}\right), s^{2}$ - variance of a variable $y$

The statistical significance of these cycles (i.e. multiple correlation coefficients $R$ ) and normal correlation coefficients $r$ were assessed with the Fisher-Snedecor test $F_{\text {calc }}>F_{\text {crit }}(6)$ (Zieliński, 1972).

$F_{\text {calc }}=\frac{n-3}{2} \frac{R^{2}}{\left(1-R^{2}\right)}$

Interference of the identified air temperature cycles (a resultant of the cycle overlapping) was established (with a cycle of $k$ ) on the basis of the following formula (7):

$f(t)=a_{o}+a t+\sum_{j=1}^{\kappa} b_{j} \sin \left(\frac{2 \pi}{\Theta_{j}} t+c_{j}\right)$

where: $t=$ time, and at - linear component.

Annual course of air temperature in cold and hot waves

The period's annual course of daily averages of 60-year air temperature values $(T)$, minimum daily averages $\left(T_{\min }\right)$ and maximum daily averages $\left(T_{\max }\right)$ in Warsaw are described by regression sinusoids (8), (9) and (10) (with at - linear component, $k=1$ ) with a frequency of , with high multiple correlation coefficients $(R)$ of $0.997,0.979$ and 0.980 , and with statistical significance at $<0.01\left(F_{\text {calc }}>F_{\text {crit }}\right)$.

$T=f(t)=7.6773+0.002239 t+$

$+10.767682 \sin (\omega t-1.845735)$

$\left.T_{\min }=f_{1} t\right)=-2.7659+0.007865 t+$

$+15.190194 \sin (\omega t-1.825587)$

$T_{\text {max }}=f_{2}(t)=16.4562-0.000200 t+$

$+9.807196 \sin (\omega t-1.810522)$

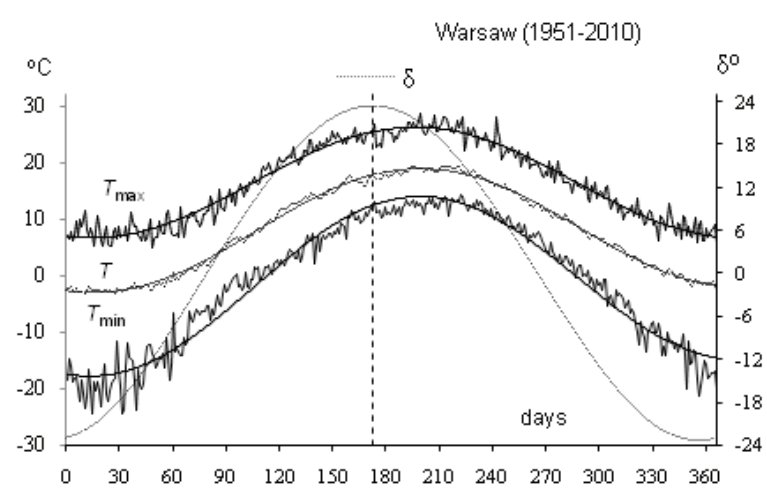

Figure 1. Annual course of air temperature in Warsaw (19512010): $T$ - 60-year daily average, $T_{\min }-$ minimum daily average, $T_{\text {max }}$ - maximum daily average, $\delta$ - angle of solar declination

The annual profiles of average daily air temperatures $(T)-$ 60 -year averages, minimum $\left(T_{\min }\right)$ and maximum $\left(T_{\max }\right)$ values in Warsaw were compared to corresponding regression sinusoids $\left.f(t), f_{1} t\right), f_{2}(t)$ and to the annual solar declination cycle $(\delta)$ derived from the IW Spencer formula (1971) (Fig. 1).

The maximum values of the air temperature regression sinusoids $\left.T=f(t), T_{\min }=f t\right)$ and $T_{\max }=f_{2}(t)$ follow the maximum Sun declination $\delta_{\max }(22$ June) with a nearly one-month delay:

$\begin{array}{cccc} & & \text { No } & \text { Date } \\ \delta_{\max } & 23.417^{\circ} & 173.000 & 22 \text { June } \\ T & 18.889^{\circ} \mathrm{C} & 197.436 & 17 \text { July } \\ T_{\min } & 13.977^{\circ} \mathrm{C} & 198.608 & 18 \text { July } \\ T_{\max } & 26.224^{\circ} \mathrm{C} & 196.561 & 15 \text { July }\end{array}$

This delay is caused by a time-shift in the daily extreme values (maximum and minimum) of the Earth's surface (ground) and the atmosphere in comparison to the upper and lower culmination of the Sun.

The annual course of the daily averages of 60-year air temperatures in Warsaw (1951-2010) depending on the daily solar declination $(\delta)$ is shown in Fig. 2a. Notably, in the second half of the year, i.e. from 22 June until the end of the year (31 December), air temperatures (upper $T$-curve) are considerably higher than those in the other half of the year (1 January -22 June) (lower T-curve). The greatest air temperature difference (of more than $10^{\circ} \mathrm{C}$ ) is observed between the spring equinox $\left(\delta=0^{\circ}, T=1.9^{\circ} \mathrm{C}\right)$ and the autumn equinox $\left(\delta=0^{\circ}, \quad T=12.6^{\circ} \mathrm{C}\right)$. Additionally, the study presents the annual profile of the lowest 60 -year values $\left(T_{\min }\right)$ and highest 60-year values $\left(T_{\max }\right)$ relative to the corresponding solar declination ( $\delta$ ) (Fig. 2b). The greatest difference, of $12.8^{\circ} \mathrm{C}$, between the two equinoxes $(\delta=0)$ is observed at the minimum daily temperatures $T_{\text {min }}\left(-5.5\right.$ and $\left.7.3^{\circ} \mathrm{C}\right)$. At the other end of the spectrum, $T_{\text {max }}$, the difference amounts to $8.7^{\circ} \mathrm{C}\left(11.4\right.$ and $\left.20.1^{\circ} \mathrm{C}\right)$.

Both cold waves $\left(\varepsilon_{i}<0\right)$ and heat waves $\left(\varepsilon_{i} \geq 0\right)$ provide a good characteristic of the deviations $\Delta T_{i}$ (remainders $\varepsilon_{i}$ ) of the daily 60 -year daily average values of measured air temperatures $T_{i}$ from the corresponding points of the regression sinusoid $f\left(t_{\mathrm{i}}\right)$ with a period of $\Theta=365.25$ days, (11a) and (11b) (Stopa-Boryczka et al., (9) 2012; Boryczka et al., 2014) (Fig. 3).

$T_{i}=f\left(t_{i}\right)+\varepsilon_{\mathrm{i}}$ 

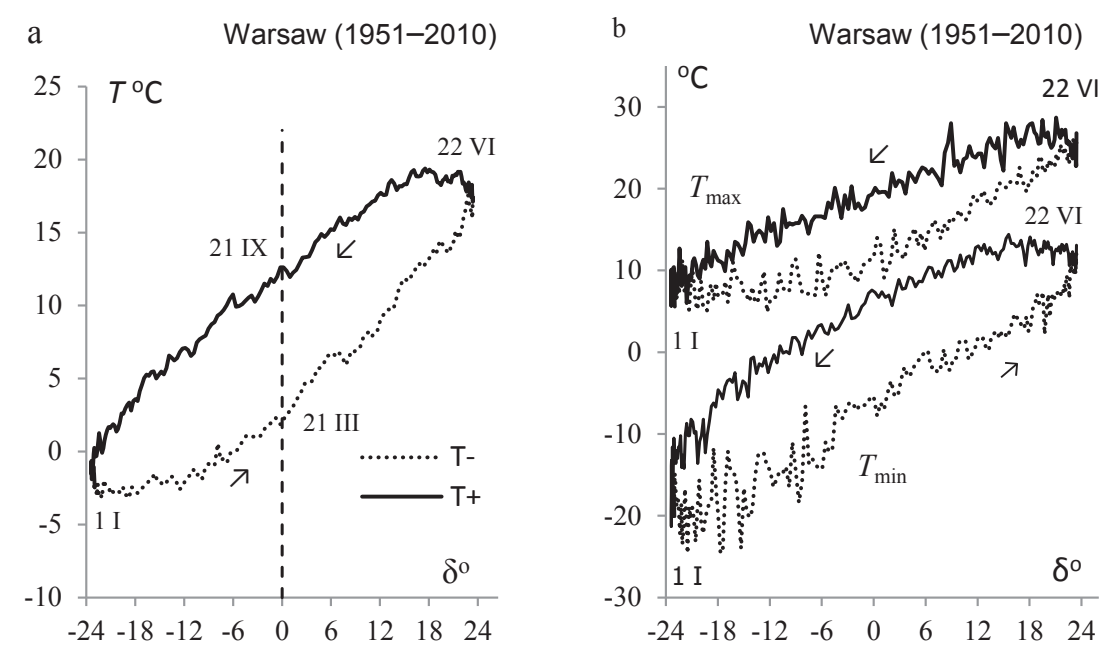

Figure 2. Annual course of air temperature in Warsaw (1951-2010) vs. angle of solar declination ( $\left.\delta^{\circ}\right)$ : a) 60-year daily average (T), b) 60-year minimum daily average $\left(T_{\min }\right) 60$-year maximum daily average $\left(T_{\max }\right)$

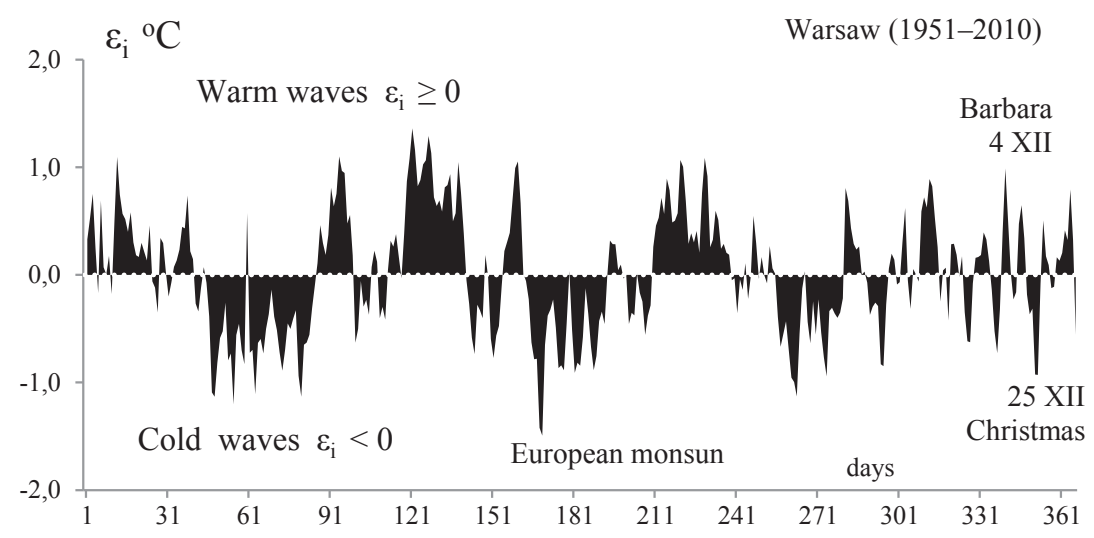

Figure 3. Warm and cold waves in Warsaw (1951-2010), $\varepsilon_{i}=T_{i}-f(t)-$ deviation of empirical points $\left(t_{i}, T_{i}\right)$ from sinusoid $f(t)$ of yearly course of air temperature

$T_{i}=a_{0}+b \sin \left(\frac{2 \pi}{365.25} t_{i}+c\right)+\varepsilon_{i}$

Earlier studies have proven that warmer and cooler spells in the annual air temperature profile (i.e. hot and cold waves) were caused by interferences between cycles lasting from single days to up to 20 days and multi-year average monthly temperature cycles (Stopa-Boryczka et al., 2006, 2011a, 2011b, 2012; Boryczka et al., 2014).

For example, cool spells in May are caused by cycles of: 6.3 , 10.4 and 16.5 days summed up with the following formula (12):

$T=12.089+0.09216 t+0.126 \sin (2 \pi t / 6.3+1.5993)+$

$+0.290 \sin (2 \pi t / 10.4-2.2842)+0.228 \sin (2 \pi t / 16.5+2.3874)$

that combined with multi-year average monthly temperature cycles with lengths of: 4.3,6.1, 8.0, 18.2, 30.2 years (and with amplitudes of $0.80,0.53,0.28,0.44$ and $0.11^{\circ} \mathrm{C}$ ). The most prominent cycles contributing here are: 16.5-day and 4.3-year cycles that produced the greatest differences of 0.46 and $1.6^{\circ} \mathrm{C}$.
Cool spells in June (the European monsoon, KossowskaCezak, 1994) are caused by the overlap of cycles with a length of $7.3,10.6$ and 16.8 days (13)

$T=16.232+0.041362 \mathrm{t}+0.229 \sin (2 \pi \mathrm{t} / 7.3+2.9757)+$ $0.314 \sin (2 \pi t / 10.6+2.9427)+0.540 \sin (2 \pi t / 16.8-1.3462)$

with long-term average monthly cycles with a length of 3.7, 9.0, 10.7 and 13.7 years (and with amplitudes of $0.601,0.401,0.319$ and $\left.0.433^{\circ} \mathrm{C}\right)$.

The autumn waves of hot weather ("Indian summer") in September and October (on days 244-304) are caused by cycles with a duration of $15.4,20.5$ and 31.8 days (14).

$$
\begin{aligned}
& T=55.877-0.164228 t+0.2764 \sin (2 \pi t / 15.4-0.9527)+ \\
& +0.1279 \sin (2 \pi t / 20.5+2.1943)+ \\
& +0.3160 \sin (2 \pi t / 31.8+2.5458)
\end{aligned}
$$


combined with long-term cycles, including in September: 6.4, $7.2,13.1,19.9$ and 38.6 years (with amplitudes of $0.611,0.656$, $0.524,0.460$ and $0.306^{\circ} \mathrm{C}$ ) and in October: $4.8,5.7,7.8$ and 19.2 years (with amplitudes of $0,643,0.862,0.515$ and $0.766^{\circ} \mathrm{C}$ ).

It is interesting to note that the December warm and cold waves (4 December and 25 December) are caused by interference between short cycles of average daily temperature with a duration of 4.6, 7.7 and 16.8 days (and amplitudes of 0.48 , 0.80 and $\left.0.70^{\circ} \mathrm{C}\right)$, as per formula (15):

$T=0.575-0.0831 \mathrm{t}+0.241 \sin (2 \pi \mathrm{t} / 4.6+0.0433)+$

$+0.404 \sin (2 \pi t / 7.7-2.1011)+0.350 \sin (2 \pi t / 16.8-1.4969)(15)$

and long term cycles of 2.9, 6.7, 8.1,16.7 and 30.7 years (with amplitudes of $1.078,1.348,0.843,1.101,0.742$ ) and, above all, of 6.7 and 16.7 years of average monthly air temperature (amplitudes of 2.7 and $2.2^{\circ} \mathrm{C}$ ).

The impact of circulation on warm and cool waves

Warm and cool waves in the annual course of daily air temperatures in Warsaw during the study period were influenced by the corresponding profile of the North Atlantic Oscillation (NAO). NAO values indicate longitudinal movement of air masses; values above zero correspond to an eastwards movement and values below zero to a westwards movement (Marsz, 1999, 2008). A change in NAO causes short warm or cool spells of several days in length. This is demonstrated by changes in annual NAO values, such as the average daily $(N A O)$, minimum $\left(N A O_{\text {min }}\right)$ and maximum $\left(N A O_{\max }\right)$ values.

The annual courses of $N A O, N A O_{\min }$ and $N A O_{\max }$ are similar to regression sinusoids (16), (17), (18) of $F(t), F_{1}(t), F_{2}(t)$ with the frequency, derived from 365 (366) values from successive days (of the 60-year period) (Fig. 4).

$N A O=F(t)=-0.033666-0.000052 t+$

$+0.03856591 \sin (\omega t-2.848821)$

$N A O_{\min }=F_{1}(t)=-4.085093+0.001626 t+$

$+1.931304 \sin (\omega t-1.910102)$

$N A O_{\max }=F_{2}(t)=3.5043-0.000052 t+$

$+1.778929 \sin (\omega t+1.067360)$

Their multiple correlation coefficients $(R=0.207, R=0.466$, $R=0.345$ ) are significant at 0.01 because the statistical values produced by the Fisher-Snedecor test $\left(F_{\text {calc }}=8.100, F_{\text {calc }}=50.21\right.$, $\left.F_{\text {calc }}=24.45\right)$ are greater than the critical value $F_{\text {crit }}=4.67$.

The maximum values of $N A O$ regression sinusoids $(N A O=F(t)$, $N A O_{\min }=F 1(t)$ and $\left.N A O_{\max }=F 2(t)\right)$ fall more than one month after the maximum angle of solar declination $\delta_{\max }(173,22 \mathrm{VI})$ :

$\begin{array}{llll}N A O & -0.00544 & 198.787 & 18 \mathrm{VII} \\ N A O_{\min } & -1.82477 & 202.349 & 21 \mathrm{VII} \\ N A O_{\max } & 1.736389 & 211.89 & 31 \mathrm{VII}\end{array}$

The lowest average daily temperatures $\left(T_{\min }\right)$ in Warsaw in the annual profile of 1 to 365.25 days (1951-2010) are strongly correlated with the lowest NAO values $\left(N A O_{\min }, r=0.899\right)$ while the highest daily averages $\left(T_{\max }\right)$ display a similar correlation with the highest $N A O$ values $\left(N A O_{\max }, r=-0.858\right)$.

Both the ranges of the lowest average daily temperature $\left(T_{\min }\right)$ in Warsaw and the lowest $N A O_{\min }$ values feature cycles of nearly identical lengths, i.e. 151.8 and 152.6 days long, with amplitudes of $11.84^{\circ} \mathrm{C}$ and $1.644^{\circ} \mathrm{C}$ respectively, and correlation coefficients of $R=0.453$ and $R=0.491$ that are statistically significant at 0.01 $\left(F_{\text {calc }}=46.733\right.$ and $F_{\text {calc }}=57.497$, and $\left.F_{\text {crit }}=4.67\right)$.

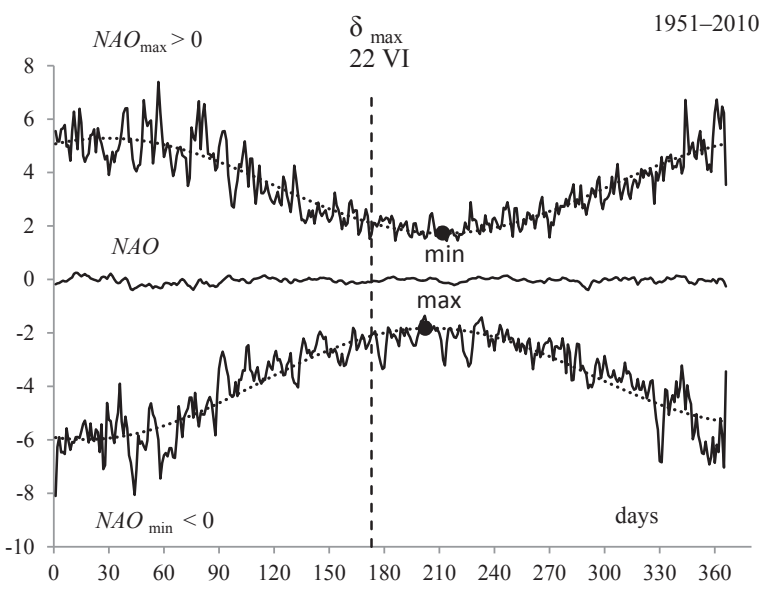

Figure 4. Annual course of the NAO (1951-2010), NAO - daily average, $N A O_{\min }-$ minimum and $N A O_{\text {max }}-$ maximum

Similarly, the ranges of the highest daily temperature $T_{\max }$ and the highest $N A O_{\max }$ feature similar cycles of 146.2 and 150.4 days in length and amplitudes of $6.03^{\circ} \mathrm{C}$ and $1.08^{\circ} \mathrm{C}$ correlated at $R=0.340$ and $R=0.428$, significant at $0.01 \quad\left(F_{\text {calc }}=23.66\right.$, $F_{\text {calc }}=40.59$ ).

Typically, when NAO values were significantly above zero Warsaw experienced a warm wave (eT $T$ alues were $\mathrm{S} N A O$ was lower than zero it experienced a wave of cool weather $(r T<0)$ (Fig. 5).

The influence of solar activity on warm and cool waves

The range of the average daily Wolf numbers $(W)$ during the study period (Fig. 6 ) features cycles with durations $\Theta$, amplitudes $b$ and phases $c$, where $R$ is the correlation coefficient and $F_{\text {calc }}$ represents the Fisher-Snedecor test (Tab.1). In the range of daily maximum Wolf numbers $\left(W_{\max }\right)$ the longest cycles equal $\Theta=122$ days and 365.25 days.

The annual profile of Wolf numbers, including daily average $W(1951-2013)$ and the daily maximum $W_{\max }$ (1951-2010), is well matched by regression sinusoid formulae of assumed frequency (19) and (20).

$W=66.832+0.00466 t+1.776792 \sin (\omega t-2,431845)$

$W_{\max }=237.2007+0.037789 t+12.604851 \sin (\omega t-2.737850$

Correlation coefficients $R=0.433$ and $R=0.385$ are significant at 0.01 (Fisher-Snedecor test $F_{\text {calc }}=41.65$ and $F_{\text {calc }}=29.059$ are greater than $F_{\text {crit }}=4.67$ ).

The maximum of the regression sinusoid of daily average Wolf numbers $W$ (1951-2013) was delayed from the maximum angle of solar declination $\delta_{\max }(173,22$ June) by more than two months (20 August) and the maximum of the sinusoid of the highest daily Wolf numbers $W_{\text {max }}(1951-2010)$ is delayed by nearly 3 months (7 IX) (Fig. 7):

$\begin{array}{llll}W & 69.69308 & 232.679 & 20 \mathrm{VIII} \\ W_{\max } & 259.2705 & 250.468 & 7 \text { IX }\end{array}$

It is important to note that in the annual cycle caused by the Earth orbiting around the Sun, the increase in the daily average temperature $T$ between January and mid-July may is also caused by the increase in solar activity (daily Wolf numbers $W$ ) and its subsequent decrease until December may also be caused by a drop in solar activity $W$ (Fig. 8). 


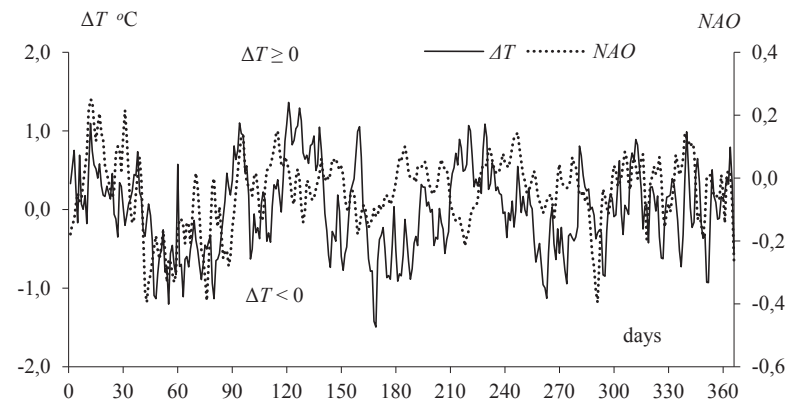

Figure 5. Warm waves $(\Delta T \geq 0)$ and cool waves $(\Delta T<0)$ in Warsaw vs. average annual course of daily NAO (1951-2010)

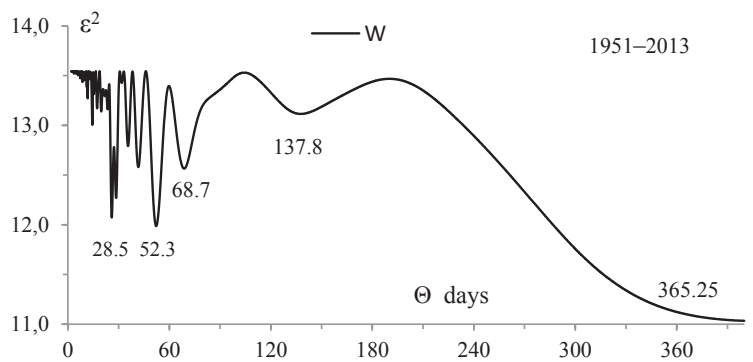

Figure 6. Spectrum of daily Wolf numbers W (1951-2013)

Table 1. Cycles of daily average Wolf numbers (1951-2013)

\begin{tabular}{|c|c|c|c|c|}
\hline $\boldsymbol{\Theta}$ days & $\mathbf{b}$ & $\mathbf{C}$ & $\mathbf{R}$ & $\mathbf{F}_{\text {calc }}$ \\
\hline 28.5 & 1.574105 & 1.952977 & 0.307 & 13.62 \\
\hline 52.3 & 1.48891 & -2.644511 & 0.339 & 17.02 \\
\hline 68.7 & 1.236791 & -0.652153 & 0.269 & 10.21 \\
\hline 137.8 & 0.662988 & 2.517657 & 0.178 & 4.29 \\
\hline 365.25 & 1.798819 & -2.545154 & 0.425 & 28.84 \\
\hline
\end{tabular}

This delay in the daily extremes (maximums and minimums) of air temperature relative to the upper and lower culmination of the Sun is not just caused by the physical process of heat energy exchange between the active surface (ground) and the atmosphere, but also by the annual profile of the Sun's activity (numbers of spots visible from the Earth on the face of the rotating Sun).

The annual change in the deviations $(\Delta T)$ of the average daily air temperatures $\varepsilon_{i}=T_{i}-f\left(t_{i}\right)$ and of the daily Wolf numbers $(W)$ tend to be synchronous (Fig. 9). There is also a coincidence of the extremes in the annual deviations of the highest average daily temperatures $\Delta T_{\max }=T-f_{2}(t)$ and the maximums of the Wolf numbers $\left(W_{\max }\right)$ (Fig. 10).

To demonstrate a high dependence of the annual air temperature course in Warsaw on Wolf numbers during the study period, a comparison was made between the regression sinusoids with the longest periods occurring in the oscillation ranges (except the annual cycles $\Theta=365.25$ days): $T=147.9$ days, $W=137.8$ days $(1951-2013), T_{\min }=151.8$ days, $T_{\max }=146.2$ days and $W_{\max }=122.0$ days. These cycles have significant multiple correlation coefficients $(R)$, respectively of $0.386,0.283,0.453$, 0.340 and $0.384\left(F_{0.01}=4.67\right)$, equations (21), (22), (23), (24) and (25).
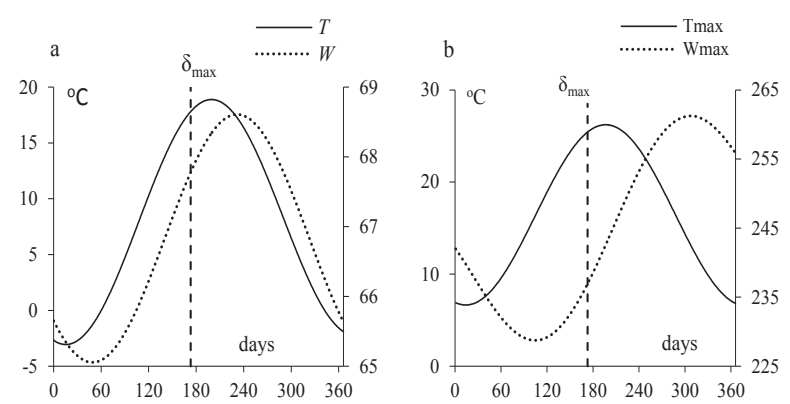

Figure 7. Annual course of air temperature in Warsaw (1951-2010) and of solar activity (Wolf numbers), a) $T$ and $W, b) T_{\max }$ and $W_{\max }$
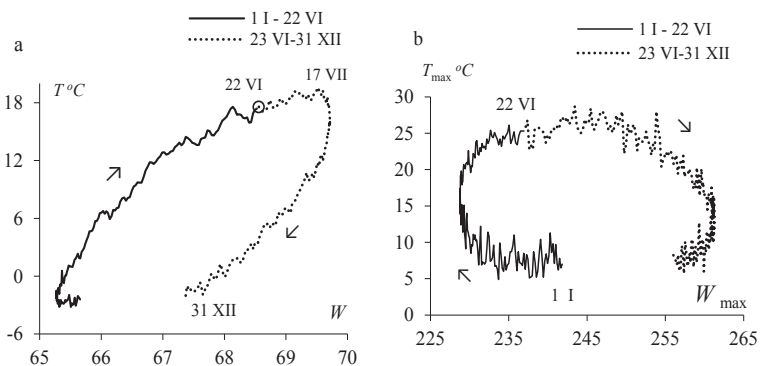

Figure 8. Dependence of air temperature in Warsaw (1951-2010) on solar activity (Wolf numbers), a) $T$ on $W, b) T_{\max }$ on $W_{\text {max }}$

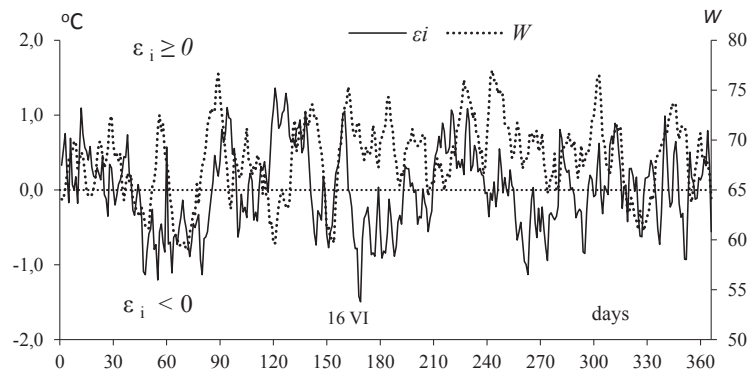

Figure 9. Warm and cool waves $\varepsilon_{i}=T_{i}-f\left(t_{i}\right)$ in Warsaw vs. Wolf numbers (W) (1951-2010)

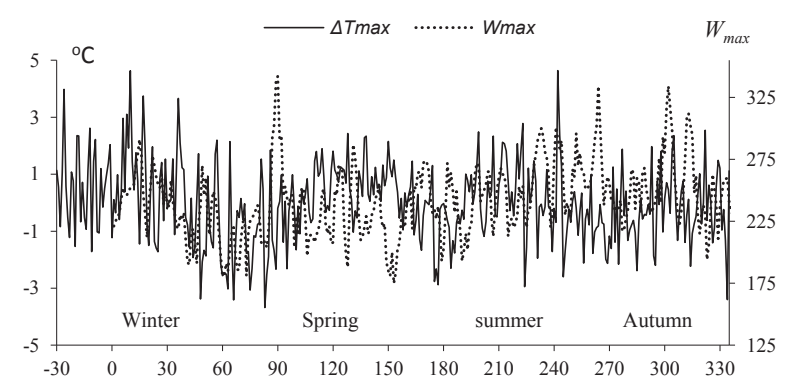

Figure 10. Warm and cool waves $\Delta T_{\max }=T_{\max }-f_{2}(t)$ in Warsaw vs. maximum daily Wolf numbers $\left(W_{\max }\right)(1951-2010)$ 
a

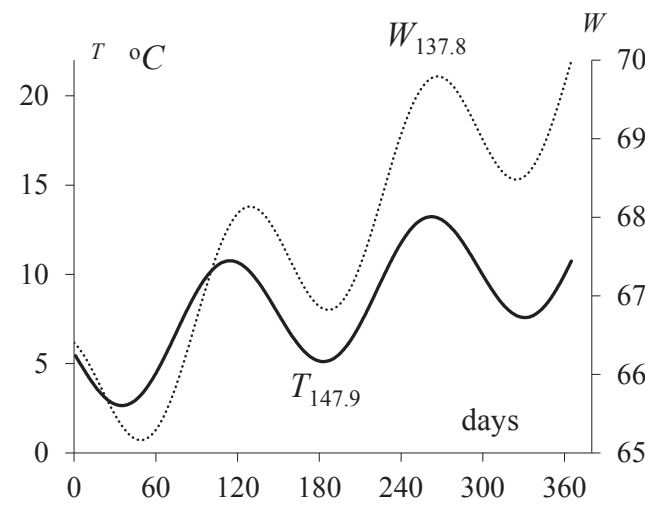

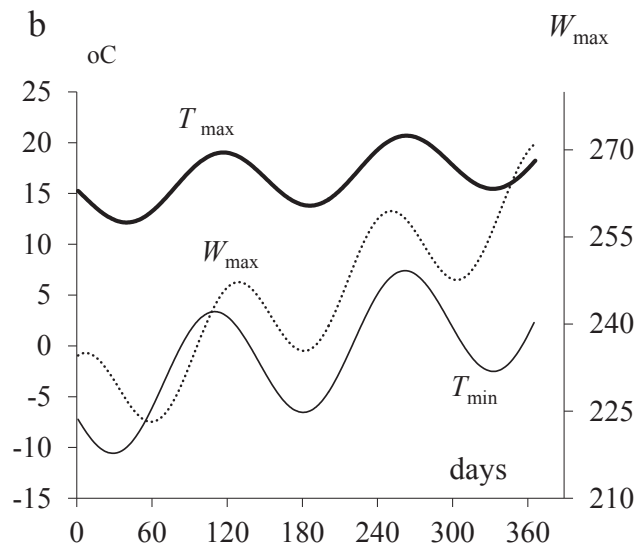

Figure 11. Annual change in air temperature in Warsaw and in Wolf numbers (1951-2010): a) daily averages (T, W); $b)$ minimum $\left(T_{\text {min }}\right)$ and maximum $\left(T_{\text {max }}\right)$ annual daily air temperatures and $W_{\max }$

$T=5.4431+0.016665 t+$ $3.419359 \sin (2 \pi t / 147.9+3.064770)$

$T_{\min }=-5.4719+0.026545 t+$ $5.929996 \sin (2 \pi t / 151.8-2.916341)$

$T_{\max }=14.6991+0.011321 t+$

$3.017739 \sin (2 \pi t / 146.2+2.916286)$

$W=65.5772+0.012035 t+$

$1.038030 \sin (2 \pi t / 137.8+2.224552)$

$W_{\max }=225.7675+0.100149 t+$

$8.766014 \sin (2 \pi t / 122.0+1.430669)$

$\begin{array}{cc}R & F_{\text {calc }} \\ 0.386 & 31.49 \\ 0.453 & 46.73 \\ 0.340 & 23.66 \\ R & F_{\text {calc }} \\ 0.385 & 31.40 \\ 0.384 & 31.31\end{array}$

There is also a noteworthy coincidence of the extremes and a trend towards an increase in the average daily air temperature $(T)$ in Warsaw with a cycle of 147.9 days and in the average daily Wolf numbers $(W)$ with the cycle of 137.8 days (1951-2013) (Fig.11a). A similar conclusion about the lowest $\left(T_{\min }\right)$ and highest $\left(T_{\max }\right)$ daily air temperatures in Warsaw being dependent on maximum daily Wolf numbers $\left(W_{\max }\right)$ can be drawn from a comparison of sinusoids with the periods $T_{\min }=151.8$ days, $T_{\max }=146.2$ days and $W_{\max }=122.0$ days (Fig.11b).

Other indications of the dependence of the climate on solar activity include, for example, synchronic fluctuations of average 11-year moving Wolf numbers $(W)$ (correlation coefficient $r=0.397$ significant at the 0.01 level) and the width $(d)$ of Picea abies spruce tree rings at Stonnglandes (Norway, 1403-1997) (Fig.12).

Other indications of the dependence of the climate on solar activity include, for example, synchronic fluctuations of average 11year moving Wolf numbers $(W)$ and the width $(d)$ of 5 trees growing in Europe: Pinus silvestris (Fortfjorddalen, Norway, 877-1994), Picea abies (Falkenstein, Germany, 1540-1995), Fodara Vedla (Italy, 1598-1990), Stonnglandes (Norway, 1403-1997) and Larix deciduas (Pinega, Russia, 1578-1990) (correlation coefficient $r=0.236$ significant at the 0.01 level) (Fig. 13).

\section{Conclusions}

The annual courses of average daily air temperatures $(T)-$ 60-year averages, minimum $\left(T_{\min }\right)$ and maximum $\left(T_{\max }\right)$ values in Warsaw were compared to corresponding regression sinusoids $f$ $(t)$, and to the annual solar declination cycle ( $\delta)$.

The maximum values of the air temperature regression sinusoids $T$ (17 July), $T_{\min }$ (18 July) and $T_{\max }$ (15 July) follow the

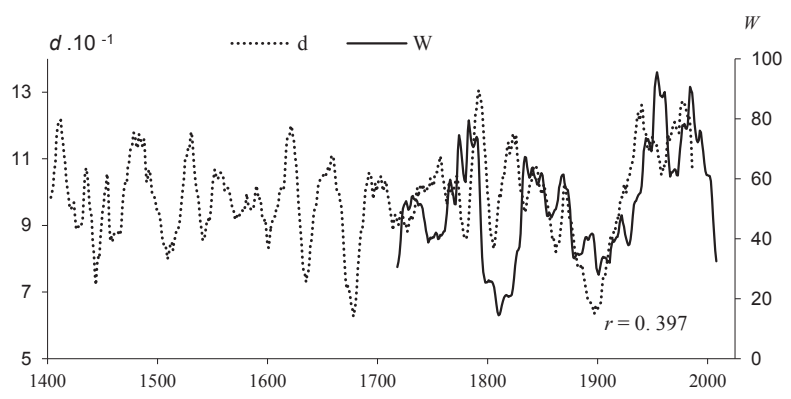

Figure 12. Synchronous fluctuation of the width of spruce tree rings (Picea abies) at Stonnglandes (1403-1997, Norway) and Wolf numbers (1700-1997) (11-year moving averages), correlation coefficient $r=0.397$

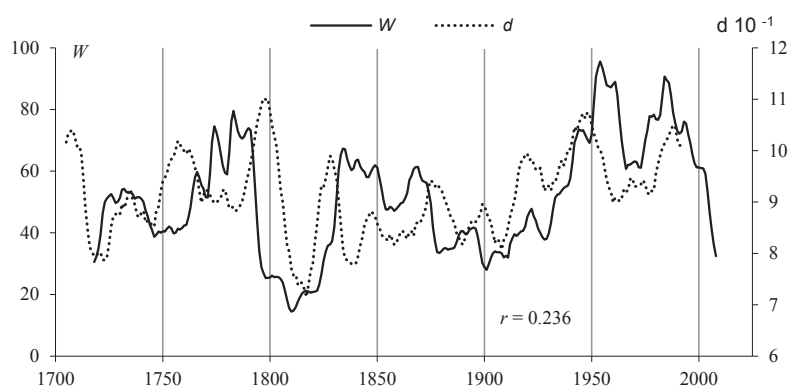

Figure 13. Synchronous fluctuations of average tree ring widths of 5 of trees growing in Europe and Wolf numbers in the years 1700-2015 (11-year moving average ), correlation coefficient $r=0.236$

maximum Sun declination $\delta_{\max }=23.4^{\circ}$ (22 June) with a nearly one-month delay. The maximum values of NAO regression sinusoid (18 July) fall more than one month after the maximum angle of solar declination $\delta_{\max }$. The maximum of the regression sinusoid of daily average Wolf numbers $W$ (1951-2013) was delayed from the maximum angle of solar declination $\delta_{\max }$ by more than two months (20 August). 
Notably, in the second half of the year, i.e. from 22 June until the end of the year (31 December), air temperatures are considerably higher than those in the other half of the year (1 January - 22 June).

The increase in the average daily air temperature $T$ observed between January and mid-July is caused not only by an increase in the angle of the Sun's declination, but also by an increase in solar activity (Wolf number $W$ ), while the subsequent decrease in temperature lasting until December is also caused by the falling $W$ numbers.

This delay in the daily extremes (maximums and minimums) of air temperature relative to the upper and lower culmination of the Sun is not only caused by the physical process of heat energy exchange between the active surface (ground) and the atmosphere, but also by the annual profile of the Sun's activity (numbers of spots visible from the Earth on the face of the rotating Sun).

Both cold waves $\left(\varepsilon_{i}<0\right)$ and heat waves $\left(\varepsilon_{i} \geq 0\right)$ provide a good characteristic of the deviations $\varepsilon_{i}$ of the daily 60 -year daily average values of measured air temperatures $T_{\mathrm{i}}$ from the corresponding points of the regression sinusoid formula $f\left(t_{\mathrm{i}}\right)$ with a period of $\Theta=365.25$ days.

Cold waves were found to generally occur at times of low daily average solar activity (60-year), while hot waves tended to coincide with high Wolf numbers. There is also a coincidence of the extremes of shorter air temperature cycles of $\Theta=147.9$ days and Wolf numbers of $\Theta=137.2$ days.

\section{References}

Bernes, C, 2003, A Warmer World. The Greenhouse Effect and Climate Change, Monitor 18, Swedish Environmental Protection Agency, SWE CLIM.

Boryczka, J, 1998, 'Zmiany klimatu Ziemi' [Changes of the Earth's climate], Wyd. Akadem. Dialog, Warszawa.

Boryczka, J, Stopa-Boryczka, M, 2004, Climate of the Europe. Past, Present, Future, Miscellanea Geographica, vol. 11, pp. 101-118.

Boryczka, J, Stopa-Boryczka, M, Kossowska-Cezak, U, Wawer, J, 2014, 'Zależność najniższych i najwyższych średnich dobowych wartości temperatury powietrza od aktywności Słońca (na przykładzie Warszawy, 1951-2010)' [The dependency of minimum and maximum, average daily air temperature on solar activity (Warsaw, 1951-2010)] Prace $i$ Studia Geograficzne, vol. 56, pp. 67-95.

Boryczka, J, 2015, 'Zmiany klimatu Ziemi' [Changes of the Earth's climate], Wyd. WGSR UW, Warsaw.

Kossowska-Cezak, U, 1994, 'O monsunie europejskim' Prz. Geof., vol.39, 1, pp. 65-73.

Marsz, A A (ed.), 1999, 'Wpływ stanu termicznego powierzchni oceanu na modyfikacje cyrkulacji atmosferycznej w wymiarze klimatologicznym' [Impact of the thermal condition of the ocean's surface on the modification of atmospheric condition in the climatological dimension]. Conference proceedings, Gdynia, 6 May 1999.

Marsz, A A, 2008, 'W sprawie genezy Oscylacji Północnego Atlantyku', Prz. Geof., vol. 53, pp.13-26.

Spencer, I W, 1971, 'Fourier series representation of the position of the sun', Search, No 2.

Stopa-Boryczka, M, Boryczka, J, Tońska, M, 2006, 'Fale chłodu i ciepła w przebiegu rocznym temperatury powietrza w Polsce'
[Cold and heat waves in annual air temperature fluctuations in Poland], [in:] Prognozy pogody w przysłowiach $i$ ich sprawdzalność w Polsce. Materiały Zakładu Klimatologii WGSR UW z X Pikniku Naukowego Radia BIS (3 VI 2006). Wyd. WGSR UW, Warsaw.

Stopa-Boryczka, M, Boryczka, J, Kossowska-Cezak, U, Wawer, J, 2011a, 'Fale chłodu i ciepła w przebiegu rocznym temperatury powietrza w Warszawie (1951-2010)' [Cold and heat waves in annual air temperature fluctuations in Warsaw (1951-2010)]. Prz. Geof., vol. 56, 3-4, pp. 181-200.

Stopa-Boryczka, M, Boryczka, J, Kossowska-Cezak, U, Wawer, $\mathrm{J}, 2011 \mathrm{~b}$, 'Heat and cold waves in an annual cycle air temperatures in Warsaw (1951-2010)', Miscellanea Geographica, vol.15, pp. 103-114.

Stopa-Boryczka, M, Boryczka, J, Kossowska-Cezak, U, Wawer, J, 2012, 'Fale chłodu i ciepła w przebiegu rocznym temperatury powietrza w Warszawie (1951-2010)', [in:] Stopa-Boryczka, M, Boryczka, J, Wawer, J, Grabowska, K, Dobrowolska, M, Osowiec, M, Błażek, E, Skrzypczuk, J, Grzęda, M, Atlas współzależności parametrów meteorologicznych $i$ geograficznych w Polsce. T. XXVI-XXVII, Z badań klimatu Mazowsza (z uwzględnieniem większych miast,Wyd. UW, pp. 43-53.

Zieliński, R, 1972, 'Tablice statystyczne', PWN, Warsaw.

http://www.cpc.ncep.noaa.gov/products/precipCWlink/pna/ month_nao_index.html data/nao.htm; data.noaa oisst. v2.html; daily NAOI.index.1948-2012.asci http://sidc.oma.be/ data /index.html; http://sidc.oma.be/sunspot-data/dailyssn. php; daily total sunspot number,. dayssn_import.txt 